\title{
Research Review on the Influence of Financing Constraints on Enterprises' Investment Efficiency
}

\author{
Yu Bai \\ Xijing University, Xi'an Shaanxi, 710123, China
}

Keywords: Financing constraints, Literature review, Investment efficiency.

\begin{abstract}
Investment activity is the most important financial activity of an enterprise, the investment efficiency of an enterprise even affects its survival, enterprise's financing capability brings dynamic source for its investment. However, because of the existence of agency problems and information asymmetry, enterprises often meet different degrees of financing constraints, which will affect enterprises' investment behaviors, this paper summarizes the relationship between financing constraints and enterprises' investment efficiency through combing related documents on financing constraints and investment efficiency.
\end{abstract}

\section{Financing constraints}

Modiglinai and Miller (1958) assumed that under the capital market of perfection competition, without the influences of transaction cost, income tax and other factors, internal and external financing can be substituted, it also suggests that enterprises' financing behavior will not affect their investment behavior. However, in actual life, the above described capital market is not exist, Myers and Majluf(1984) found that the existence of information asymmetry improved enterprises' external financing costs, which caused that enterprises have to give up some NPV $>0$ projects. FHP(1988) thought that the reason for enterprises' internal capital costs lower than external capital costs is the existence of transaction, tax advantages, agency cost, financial crisis and information asymmetry. Furtherly, they specifically studies and analyzed the difference between internal financing costs and external financing cost of managers and potential new investors or creditors caused by information asymmetry. And, they defined this phenomenon that financing costs difference constrained enterprises' investment behavior as financing constraints. The above view is regarded as generalized financing constraints. Therefore, every enterprise is faced with different degrees of financing constraints.

Another point of view is to define financing constraints from a narrow sense. It limits enterprises' financing constraints into external financing constraints, it means that enterprises are facing factors like higher external financing costs or credit rationing, are constraints faced by enterprises when they face capital shortage. Almeida and Campello(2001) furtherly divided enterprises' financing constraints faced in external financing into constraints on financing quantity and financing price. Financing amount constraints are researched on the basis of credit rationing theory, they think that not all the enterprises can get the external funds that they need, enterprises have to give up some NPV $>0$ projects because they did not get financial support. While financing price constraints are based on financing pecking order theory, the implicit assumption is that as long as enterprises can pay a high cost, they can always get financing. Guariglia(2008) divided enterprises' financing constraints into internal financing constraints and external financing constraints. Summarizing existing documents, most of scholars limited financing constraints into external financing constraints, and not divided into financing price constraints and financing quantity constraints.

\section{Investment efficiency}

For a long time, investment efficiency has always been the key issues concerned by scholars, most of the scholars studied the related factors that affect enterprises' investment efficiency from the angle of inefficient investment. Common inefficient investment behaviors are over-investment and 
under-investment (give up investment in NPV $>0$ projects or invest in VPN $<0$ projects).

Different scholars have different measurements for investment efficiency, commonly use Richardson model (Richardson,2006) to measure enterprises' investment efficiency, this model selects INV to represent capital investment; Q represents Tobin Q value; LEV represents asset-liability ratio; CASH represents cash holdings; AGE represents enterprises' listing age; SIZE represents company scale; RET represents annual return on stock calculated monthly, see model (1).

The residual error ( $\varepsilon$ ) of model (1) is the difference between real investment and expected investment, when $\varepsilon$ is greater than zero, the real investment level (INV I,t) is greater than the expected investment level ( INV i,e), this means over-investment, when $\varepsilon$ is less than zero, the real investment level (INV I,t) is less than the expected investment level （INV i,e ), this means under-investment,

$$
\begin{aligned}
I N V t= & \alpha_{0}+\alpha_{1} Q_{t-1}+\alpha_{2} L E V_{t-1}+\alpha_{3} C_{A S H} H_{t-1}+\alpha_{4} A G E_{t-1}+\alpha_{5} S_{I Z E_{t-1}}+\alpha_{6} R E T_{t-1}+\alpha_{7} I N V_{t-1}+ \\
& \sum Y E A R+\sum I N D U S T R Y+\varepsilon_{0}
\end{aligned}
$$

This paper used this model to measure the investment efficiency of non-financial listed companies in our country during 2006 2014, see table 1. Note: in model (1), YEAR and INDUSTRY respectively represents industrial and annual dummy variable. CSRC(China Securities Regulatory Commission) issued the latest CSRC industry classification in 2012, in order to ensure consistency, therefore, industry classification of 2012-2014 is kept same with that of 2011.

Table 1. Descriptive statistics of the investment efficiency of listed companies during 2006 2014

\begin{tabular}{lrrrrr}
\hline & Sample number & Minimum value & Maximum value & Mean value Standard deviation \\
\hline Investment efficiency & 14662 & -11.6381 & 13.4483 & 0.000000 & 0.9991129 \\
\hline Over-investment & 5565 & 0.0001 & 13.4483 & 0.693282 & 1.1245429 \\
\hline Under-investment & 9097 & -11.6381 & -00001 & -0.424109 & 0.6012082 \\
\hline
\end{tabular}

From table 1 we can see that most of the listed companies in our country are facing problems of under-investment (9097 samples in 14662 sample companies). The quantity of over-investment samples (5565) is smaller than that of under-investment samples (9097), but with greater degree (mean value is 0.693282 )

Table 2. Descriptive statistics of annual investment efficiency during 2006 2014

\begin{tabular}{lllllll}
\hline & $\begin{array}{l}\text { Sample } \\
\text { number }\end{array}$ & $\begin{array}{l}\text { Over-investment } \\
\text { samples }\end{array}$ & $\begin{array}{l}\text { Under- } \\
\text { investment } \\
\text { samples }\end{array}$ & $\begin{array}{l}\text { Minimum } \\
\text { value }\end{array}$ & $\begin{array}{l}\text { Maximum } \\
\text { value }\end{array}$ & $\begin{array}{l}\text { Standard } \\
\text { deviation }\end{array}$ \\
\hline 2006 & 1268 & $39 \%$ & $61 \%$ & -11.0704 & 7.9592 & 1.0709504 \\
\hline 2007 & 1237 & $43 \%$ & $57 \%$ & -11.6381 & 9.4785 & 1.3065491 \\
\hline 2008 & 1272 & $38 \%$ & $62 \%$ & -6.6851 & 9.5277 & 0.9767929 \\
\hline 2009 & 1423 & $37 \%$ & $63 \%$ & -7.5808 & 9.4664 & 0.9611490 \\
\hline 2010 & 1481 & $36 \%$ & $64 \%$ & -7.9077 & 10.6065 & 1.0474713 \\
\hline 2011 & 1621 & $36 \%$ & $64 \%$ & -5.4200 & 10.4466 & 0.9323858 \\
\hline 2012 & 1927 & $35 \%$ & $65 \%$ & -5.0636 & 13.4483 & 0.9987042 \\
\hline 2013 & 2202 & $39 \%$ & $61 \%$ & -10.7609 & 10.4057 & 0.9422842 \\
\hline 2014 & 2231 & $39 \%$ & $61 \%$ & -5.9029 & 12.0586 & 0.8570686 \\
\hline
\end{tabular}

From table 2 we also can see that under-investment samples during 2006 2016 is greater (proportion of every year is mostly over 60\%).

\section{Financing constraints and investment efficiency}

\section{Research on the relation between financing constraints and investment-cash flow sensitivity.}

Scholars carries out a large amount of researches on the relation between financing constraints and investment-cash flow sensitivity, but different scholars selected different financing constraints indicators and had different results, with the constant depth of research, scholars found that agency 
problem is one of the key factors affecting investment-cash flow sensitivity.

Fazzari,Hubbard And Petersen(1988), used dividends payment rate to measure enterprises' financing constraints, first put forward that it is positive correlation between financing constraints and investment- cash flow sensitivity. While Kappan and zingales(1997) used the 49 companies seriously influenced by financing constraints in Fazzari,Hubbard And Petersen(1988) as research samples, through qualitative and quantitative methods to judge enterprises' financing constraints. At last, they though there is no boring positive correlation between financing constraints and investment-cash flow sensitivity.

Scholars in our country have carried out a large number of empirical researches on relations between financing constraints and investment-cash flow sensitivity, and made a further exploration on the motivation on the sensitivity. Zhao Jianfeng and Yin Hang (2006) took data of listed companies in our country during 2000 2003 as research samples, used liabilities level and enterprises scale as indicator, comprehensively considered enterprises' internal financing constraints, empirical results showed that there is positive correlation between financing constraints and investment- cash flow sensitivity.

Lian Yujun and Cheng Jian (2007) found that there is negative correlation between financing constraints and investment- cash flow sensitivity. For enterprises influenced little by the financing constraints, the investment-cash flow sensitivity was originated from agency problems, while for enterprises influenced greatly by the financing constraints, information asymmetry was the main reason for their investment-cash flow sensitivity, and these enterprises were more trend to under-investment.

Qu Wenzhou and so on (2011) selected agent variable of financing constraints as the degree of information asymmetry, research showed that enterprises with high degree of information asymmetry showed strong investment-cash flow sensitivity. While there is no boring positive correlation between financing constraints and investment-cash flow sensitivity. When enterprises are faced with different degrees of financing constraints, the reasons for investment-cash flow sensitivity are also different.

\section{Research on financing constraints and investment efficiency.}

For researches on the influence of financing constraints on enterprises investment level and inefficient investment, scholars mainly focused on the influences of financing constraints on enterprises' investment level and investment efficiency. On one hand, they furtherly classified insufficient investment, studied the influences of financing constraints on insufficient investment like over-investment, under-investment and escalating commitment. On the other hand, some scholars furtherly classified enterprises' financing constraints, that are equity financing constraints and creditor right financing constraints, studied the influences of equity financing constraints and creditor right financing constraints on enterprises' investment efficiency and made a deep analysis on its mechanism.

Lian Yujun and Su Zhi (2009) found that the average investment efficiency of listed companies in our country is just $72 \%$, financing constraints caused that the investment level of listed companies is 20\%-30\% lower than the optimal level.

Yu Honglin (20120 started from China’s system background, found that when enterprises did not get bank loan and faced with financing constraints, there would be under-investment, compared with non state-owned enterprises, the investment states of stated-owned enterprises changed obviously and had over-investment, while non stated-owned enterprises had no over-investment behaviors, and during the financial crisis, the under-investment degree of non stated-own enterprises (did not get loan) was more serious than during the whole sample period. They thought that the key factor for this phenomenon of non stated-owned enterprises was the function of bank liabilities.

Enterprises' external financing obstacles is the important factor that restricts its development, in our country, under the way that bank credit as main external financing way, the availability of bank credit influenced the degree of enterprises' financing constraints. Tang Yang and Gao Jiaxu (2012) set the availability of bank credit as entry point, found that the availability of bank credit is positively correlated with occurring probability of escalating commitment. Furtherly, in enterprises with 
escalating commitment, they found that the availability of bank credit also obviously increased enterprises' escalating commitment.

Research on the relations among financing constraints, investment efficiency and the third factor.

This kind of research was carries out on the basis of researches on relations between financing constraints and investment efficiency. With the spread of research on financing constraints and investment efficiency, scholars found that the influence degree of financing constraints on enterprises' investment efficiency and mechanism will be influenced by other factors, Shen Huihui and so on (2012) took environment uncertainty into consideration, studied the influence of this factor on financing constraints and investment efficiency, and made a detailed analysis on enterprises' different situations.

\section{References}

[1] Qu Wenzhou, Xie Yalu, Ye Yumei. Information Asymmetry, Financing Constraints and Investment-Cash Flow Sensitivity, Economic Research, 2011(3):105-117.

[2] Zhang Lifang. Financing Constraints, High Cash Holdings and Investment Efficiency. Journal of Shanxi University of Finance and Economics, 2014(4): 114-124Z.

[3] Lian Yujun, Su Zhi. Financing Constraints, Uncertainty and Investment Efficiency of Listed Companies. Management Review, 2009(1):19-26.

[4] Fazzari S., G. Hubbard, and B. Peterson. Financing constraints and corporate investment. Brookings Papers on Economic Activity,1988, (1): 141-195.

[5] Kaplan. S, zingales. L. Do investment-cashfloe sensitivities provide useful measures of financing constraints? quarterly journal of economics, 1997, 112(1):169-215.

[6] Richardson. S, 2006, Over Investment Of Free Cash Flow, Review of Accounting Studies, (11):159- 189. 